\title{
The effect of rosemary herb as a dietary supplement on performance, egg quality, serum biochemical parameters, and oxidative status in laying hens
}

\author{
M. Alagawany ${ }^{1}$ and M.E. Abd El-Hack \\ Zagazig University, Faculty of Agriculture, Poultry Department \\ Zagazig 44111, Egypt
}

KEY WORDS: rosemary powder, performance, blood profile, antioxidant status, laying hens

Received: 23 June 2015

Revised: 1 November 2015

Accepted: 25 November 2015

${ }^{1}$ Corresponding author:

e-mail: dr.mahmoud.alagwany@gmail.com

\begin{abstract}
The aim of this study was to evaluate the effect of rosemary herb on performance, egg quality, blood profile, immune function and antioxidant status in Hi-sex Brown laying hens. A total of 96 thirty-six-week-old laying hens were assigned to 4 dietary treatments ( 6 replications of 4 hens per group) and were fed the control diet or diets supplemented with 3,6 or $9 \mathrm{~g} \cdot \mathrm{kg}^{-1}$ of rosemary powder until 52 weeks of age. There were no differences in live body weight, feed consumption, feed conversion ratio or egg weight due to adding rosemary. Egg numbers and egg mass linearly increased with rosemary supplementation. Adding rosemary to laying hen diets resulted in a linear increase in yolk percent $(P<0.05)$ and yolk-to-albumen ratio $(P=0.01)$, and a decrease in albumen percent $(P<0.05)$ compared with the non-supplemented group. Serum constituents were not significantly influenced by rosemary, except urea, total cholesterol, immunoglobulins $\mathrm{M}(\mathrm{IgM})$ and $\mathrm{A}(\mathrm{IgA})$ concentrations. In comparison with the control group, the diet enriched with rosemary numerically reduced serum triglycerides, cholesterol and LDL-cholesterol concentrations, but HDL-cholesterol level was elevated with the same addition. Superoxide dismutase activity was linearly and quadratically ( $P=0.007$ and 0.002 , respectively) increased in rosemary groups, and was maximized $\left(290 \mathrm{U} \cdot \mathrm{ml}^{-1}\right)$ at $6 \mathrm{~g} \cdot \mathrm{kg}^{-1}$ diet. In conclusion, rosemary supplemented up to $6 \mathrm{~g} \cdot \mathrm{kg}^{-1}$ diet can be used as effective feed additive to improve performance, immunity and antioxidant status in laying hens.
\end{abstract}

\section{Introduction}

Medicinal plants and their bioactive components are presently attaining importance in animal and poultry production as well as health care systems because of their broad beneficial effects promoting growth and production, immune enhancement, and safeguarding health (Farag et al., 2014; Alagawany et al., 2015a,b). Studies have described various biological impacts and protective effects of rosemary (Rosmarinus officinalis L.), including antioxidant, antibacterial, anti-inflammatory, anticancer, immunomodulatory and health-promoting activities (FlorouPaneri et al., 2006; Chun et al., 2014).

Phytogenic feed additives (PFA), including rosemary, exert their antioxidant mechanism via eradication of free radicals, constitution of chelates with metal ions, and prevention or reduction of oxidation (Rice-Evans et al., 1995). Certain reports stated that dietary herbal plants or their essential oils improved growth and productive performance (Alçiçek et al., 2003; Basmacioğlu Malayoğlu et al., 2004), while 
others observed no such effects (Lee et al., 2003; Papageorgiou et al., 2003). Rosemary powder, a spice produced by drying the leaves of the rosemary herb, contains a large number of different phenolic compounds with biological activities, such as carnosol, carnosic acid, rosmanol and epirosmanol. Carnosic acid is the most active antioxidant present in rosemary powder or extract (Angioni et al., 2004) with an antioxidant activity approximately three times higher than carnosol and seven times higher than synthetic antioxidants.

The main objectives of the present study were to evaluate the ability of different levels of rosemary to improve productive performance, egg quality criteria and blood metabolites, as well as oxidative status parameters of laying hens during the experimental period (from 36 to 52 week of age).

\section{Material and methods}

This study was conducted at Poultry Research Farm, Department of Poultry, Faculty of Agriculture, Zagazig University (Egypt). All of the experimental procedures were carried out according to the Local Experimental Animals Care Committee, and approved by the institutional ethics committee. The birds were cared for using husbandry guidelines derived from Zagazig University standard operating procedures.

\section{Birds, experimental design and diets}

Ninety-six Hi-sex Brown laying hens were used in the experiment. A completely randomized design was used, with six replications of 4 hens each; four birds were housed per wire cage $(50 \times 50 \times 45 \mathrm{~cm})$. The cages were equipped with a nipple drinker and trough feeders. The bird house was provided with programmable lighting and adequate ventilation. The lighting programme at the start of the trial was $14 \mathrm{~h}$ of light and was increased by 15 min each week to $17 \mathrm{~h}$ of light. The diets and water were provided $\mathrm{ad}$ libitum throughout the experiment. The control diet (2800 $\mathrm{kcal}$ of $\mathrm{ME} \cdot \mathrm{kg}^{-1}$, about $18 \% \mathrm{CP}$ ) was formulated to meet the nutrient recommendations of the Hi-sex Brown management guide, which meet or exceed the NRC (1994) recommendations, as shown in Table 1 . The four experimental dietary treatments were: 1. control (basal diet with no additive), 2. control diet with $3 \mathrm{~g} \cdot \mathrm{kg}^{-1}$ of rosemary powder, 3 . control diet with $6 \mathrm{~g} \cdot \mathrm{kg}^{-1}$ of rosemary powder, and 4 . control diet with $9 \mathrm{~g} \cdot \mathrm{kg}^{-1}$ of rosemary powder; the diets were fed as a mash. The experiment lasted 16 weeks (between 36 and 52 week of age). Rosemary powder as a commercial product was purchased from Free Trade Egypt Company, Behira (Egypt).
Table 1. Composition of control diet

\begin{tabular}{lc}
\hline Ingredient & $\mathrm{g} \cdot \mathrm{kg}^{-1}$ \\
\hline Yellow maize & 567.1 \\
Soyabean meal (44\% CP) & 286.2 \\
Soyabean oil & 31.3 \\
Limestone & 93.3 \\
Dicalcium phosphate & 14.5 \\
$\mathrm{NaCl}$ & 3.00 \\
Vitamin-mineral premix & 3.00 \\
DL-methionine & 1.60 \\
Calculated analysis & \\
\multicolumn{1}{l}{$\mathrm{ME}, \mathrm{kcal}^{2} \cdot \mathrm{kg}^{-1}$} & 2800 \\
$\quad$ crude protein & 175.1 \\
\hline
\end{tabular}

1 vitamin-mineral premix provided per $\mathrm{kg}$ diet: IU: vit. A 8000, vit. $D_{3} 1300$; $m$ g: vit. $E 5$, vit. $K 2$, vit. $B_{1} 0.7$, vit. $B_{2} 3$, vit. $B_{6} 1.5$, vit. $B_{12} 7$, biotin 0.1 , folic acid 1 , pantothenic acid 6 , niacin $20, \mathrm{Mn} 60$, Zn 50 , Cu 6, I 1 , Se 0.5 , Co $1 ;{ }^{2}$ calculated according to NRC (1994)

\section{Data collection and egg parameters}

Laying hens were weighed at the beginning and the end of the experiment. Feed consumption (FC) was recorded weekly and adjusted for mortality; the feed conversion ratio (FCR) (grams of feed consumed per gram of egg produced) was calculated. Egg weight (EW) and egg number (EN) were recorded daily to calculate the egg mass (EM) as $\mathrm{EN} \times \mathrm{EW}$.

\section{Egg quality criteria}

Eggs were examined for interior and exterior quality. Egg components were measured monthly using three eggs from each treatment replicate. Eggs were weighed, then their length and width were determined before breaking. The egg was carefully broken on a glass plate $(35 \times 25 \mathrm{~cm})$ to measure both internal and external egg quality characteristics. Yolks were separated from albumen. Egg shells were cleaned of any adhering albumen. Albumen weight was calculated by subtracting the weight of yolk and shell from the whole egg weight. The egg shape index was computed as the ratio of egg width to length, the yolk index as the average yolk height divided by yolk diameter $(\mathrm{mm})$ following removal of the yolk from the albumen. Yolk height was measured by means of tripod micrometer reading to the nearest $0.01 \mathrm{~mm}$, while yolk diameter was measured by a vernier caliper to the nearest $0.05 \mathrm{~mm}$. The Haugh unit was calculated as: Haugh units $(\%)=100 \times \log$ $\left(\mathrm{H}+7.57-1.7 \mathrm{~W}^{0.37}\right)$, where $\mathrm{H}$ is the height of the albumen and $\mathrm{W}$ is the weight of the egg. The eggs were examined for shell quality on the basis of shell thickness (with shell membrane) that was measured by a micrometer. Shell thickness $(\mu \mathrm{m})$ is given as the mean value of measurements at three locations on the eggs (air cell, equator, sharp end). 


\section{Blood sampling and laboratory analyses}

Blood samples were randomly collected from six birds per treatment from the wing vein into sterilized tubes that were closed with rubber stoppers. Samples were left to coagulate and centrifuged at $3500 \mathrm{rpm}$ for $15 \mathrm{~min}$ to obtain serum, and the serum samples were kept in Eppendorf tubes at $-20^{\circ} \mathrm{C}$ until analysed. The following serum biochemical parameters: total protein $\left(\mathrm{g} \cdot \mathrm{dl}^{-1}\right)$, albumin $\left(\mathrm{g} \cdot \mathrm{dl}^{-1}\right)$, urea $\left(\mathrm{g} \cdot \mathrm{dl}^{-1}\right)$, triglycerides (TG; $\left.\mathrm{mg} \cdot \mathrm{dl}^{-1}\right)$, total cholesterol $\left(\mathrm{mg} \cdot \mathrm{dl}^{-1}\right)$, highdensity lipoprotein (HDL) cholesterol $\left(\mathrm{mg} \cdot \mathrm{dl}^{-1}\right)$, low-density lipoprotein (LDL) cholesterol $\left(\mathrm{mg} \cdot \mathrm{dl}^{-1}\right)$, and immunoglobulin $\mathrm{G}(\operatorname{IgG}), \mathrm{M}(\operatorname{IgM})$ and $\mathrm{A}(\operatorname{IgA})$ levels were determined spectrophotometrically using commercial diagnostic kits from Biodiagnostic Co. Giza (Egypt), according to Akiba et al. (1982).

For antioxidant assays, serum samples were subjected to measurement of superoxide dismutase (SOD) activity as well as reduced glutathione (GSH) and malondialdehyde (MDA) concentrations by spectrophotometric methods using a spectrophotometer (Hitachi, Japan). SOD activity was measured by the xanthine oxidase method, which monitors the inhibition of reduction of nitroblue tetrazolium by the sample (Winterbourn et al., 1975). The GSH concentration was analysed according to Beutler et al. (1963). The MDA level was analysed with 2-thiobarbituric acid (TBA), monitoring the change of absorbance at $532 \mathrm{~nm}$ with a spectrophotometer (Jensen et al., 1997).

\section{Statistical analysis}

Data were subjected to the ANOVA procedure for a completely randomized design using the GLM procedures of SPSS (version, 17.0; 2008). Orthogonal polynomial contrasts were used to test the linear and quadratic effects of the increasing levels of supplementation of rosemary herb.

\section{Results and discussion}

\section{Hen productive performance}

The effect of the dietary rosemary supplement on the performance of laying hens during the experimental period is shown in Table 2 . There were no linear or quadratic differences $(P<0.05)$ in final body weight (FBW), FC, FCR and EW due to rosemary treatments in different phases. But EN and EM were significantly (linearly; $P<0.05$ ) increased with rosemary supplementation compared with the basal diet. The mortality rate was nil in all treatments and all diet formulations. The rosemary diets were consumed without any palatability problems. The results of the
Table 2. Effects of rosemary powder on performance of laying hens from 36 to 52 week of age $(n=6)$

\begin{tabular}{|c|c|c|c|c|c|c|c|}
\hline \multirow[b]{2}{*}{ Performance } & \multicolumn{4}{|c|}{ Rosemary powder, $\mathrm{g} \cdot \mathrm{kg}^{-1}$} & \multirow{2}{*}{ SEM $^{1}$} & \multicolumn{2}{|l|}{$P^{2}$} \\
\hline & 0 & 36 & $6 \quad s$ & 9 & & linear & quadratic \\
\hline \multicolumn{8}{|l|}{ Body weight, g } \\
\hline initial & 1604 & 1667 & 1645 & 1634 & 21.84 & 0.726 & 0.409 \\
\hline final & 1822 & 18421 & 1780 & 1773 & 20.85 & 0.270 & 0.753 \\
\hline $\begin{array}{l}\text { Daily feed } \\
\text { consumption, } \mathrm{g}\end{array}$ & 87.13 & 386.39 & 94.45 & 95.45 & 2.21 & 0.108 & 0.843 \\
\hline $\begin{array}{l}\text { Feed consumed } \\
\text { per g egg } \\
\text { produced }\end{array}$ & 1.98 & 1.62 & 1.71 & 1.83 & 0.07 & 0.584 & 0.134 \\
\hline Egg weight, g & 63.22 & 261.92 & 64.62 & 63.30 & 0.52 & 0.541 & 0.993 \\
\hline Egg number & 21.69 & $9 \quad 26.15$ & $5 \quad 26.04$ & 26.06 & 0.68 & 0.025 & 0.080 \\
\hline $\begin{array}{r}\text { Total egg mass, } \\
\mathrm{g} \text { of egg/hen }\end{array}$ & 1368 & 1615 & 1687 & 1648 & 44.83 & 0.017 & 0.083 \\
\hline
\end{tabular}

current study are in line with the findings of Cho et al. (2014), who found that phytogenic feed additives (PFA) supplementation to the basal diet had no effect on feed intake (FI) or FCR compared with an unsupplemented diet. Similarly, Radwan et al. (2008) noted that dietary rosemary increased egg production, EM and improved FCR, while the FI was not statistically affected.

Medicinal plant supplementation to poultry diets can improve FCR (Hong et al., 2012). Some studies observed improvements in body weight, body weight gain and FCR of chickens when birds fed $0.5 \%$ rosemary powder (Radwan et al., 2008). In the present study supplementing rosemary up to $0.6 \%$ of layer diets led to numerical improvement in EN and EM at all ages. The improvement in egg production parameters with phytogenic additive supplementation may be due to the provision of certain compounds that improve digestion and absorption of nutrients in the digestive tract. Also, it could be attributed to the biological activity of phenolic compounds such as carnosol and carnosic acids that are found in rosemary and are able to cause greater feed efficiency and utilization, resulting in improved productive performance (Bozin et al., 2006). Also, Moreno et al. (2006) stated that rosmarinic and carnosic acids may be the key bioactive antimicrobial compounds present in rosemary. Dietary feeding of essential oil extracted from medicinal plants increased the secretion of digestive enzymes, so enhanced nutrient digestibility and improved the performance of broilers (Jang et al., 2004). In the present study, the findings indicate that the supplementation of $0.6 \%$ rosemary to laying hen diets can give the best productive performance in terms of EN and EM. 


\section{Egg quality parameters}

The effects of rosemary supplementation on egg quality parameters are illustrated in Table 3. Addition of rosemary to laying hen diets resulted in a significant linear increase in yolk percent $(P<0.05)$ and yolk-to-albumen ratio $(P=0.01)$, and decrease in albumen percent $(P<0.05)$ compared with the nonsupplemented group. These results partially agree with Radwan et al. (2008), who showed that yolk weight and yolk index were significantly $(P<0.05)$ increased by rosemary supplementation to layer diets; the highest yolk index value was seen in the $0.5 \%$ rosemary group. In the present study, compared with the control diet, shell thickness was significantly (quadratically; $P=0.006$ ) increased with the dietary rosemary level, obtaining the highest values of shell thickness at $3 \mathrm{~g} \cdot \mathrm{kg}^{-1}$ diet. The Haugh unit score was significantly (quadratically; $P<0.05$ ) decreased with increasing rosemary supplementation up to $6 \mathrm{~g} \cdot \mathrm{kg}^{-1}$ diet. Increased shell thickness by addition of rosemary may be attributed to carnosic and rosmarinic acids; the main components in rosemary having antioxidant and antimicrobial activities (Moreno et al., 2006). A study by Bölükbaşi et al. (2008) revealed that Haugh units and yolk percent were decreased by rosemary oil supplementation to layer diets, but the albumen percent was not affected. The Haugh unit score is a key indicator of interior egg quality, and it was decreased by diets supplemented with rosemary oil (Botsoglou et al., 2005). Pertinent reports on the use of rosemary herb in hen feeding have not yet been presented in the literature.

Table 3. Effects of rosemary powder on egg quality criteria of laying hens from 36 to 52 week of age $(n=6)$

\begin{tabular}{|c|c|c|c|c|c|c|c|}
\hline \multirow{2}{*}{$\begin{array}{l}\text { Egg quality } \\
\text { criteria }\end{array}$} & \multicolumn{4}{|c|}{ Rosemary powder, $\mathrm{g} \cdot \mathrm{kg}^{-1}$ diet } & \multirow{2}{*}{ SEM ${ }^{1}$} & \multicolumn{2}{|l|}{$P^{2}$} \\
\hline & 0 & 3 & 6 & 9 & & linear & quadratic \\
\hline Albumen, \% & 66.48 & 66.76 & 65.28 & 64.72 & 0.36 & 0.040 & 0.536 \\
\hline Yolk, \% & 24.36 & 23.78 & 25.35 & 26.39 & 0.36 & 0.013 & 0.196 \\
\hline Shell, \% & 11.84 & 12.14 & 12.05 & 11.57 & 0.20 & 0.657 & 0.391 \\
\hline $\begin{array}{l}\text { Egg } \\
\text { shape index }\end{array}$ & 79.30 & 81.72 & 78.41 & 78.96 & 0.64 & 0.453 & 0.467 \\
\hline $\begin{array}{l}\text { Shell } \\
\text { thickness, } \mu \mathrm{m}\end{array}$ & 0.35 & 0.43 & 0.39 & 0.38 & 0.01 & 0.587 & 0.006 \\
\hline Yolk index & 36.67 & 40.06 & 41.14 & 40.50 & 0.58 & 0.240 & 0.410 \\
\hline $\begin{array}{l}\text { Yolk } \\
\text { albumen ratio }\end{array}$ & 0.38 & 0.36 & 0.40 & 0.42 & 0.01 & 0.010 & 0.174 \\
\hline $\begin{array}{l}\text { Haugh } \\
\text { unit score }\end{array}$ & 84.30 & 81.68 & 78.77 & 88.77 & 1.25 & 0.277 & 0.005 \\
\hline
\end{tabular}

${ }^{1}$ SEM - standard error of means; ${ }^{2}$ linear and quadratic effect of rosemary supplementation

\section{Blood constituents}

Biochemical blood parameters usually reflect the health of an animal. These parameters are vital indicators of the nutritional and physiological status of birds and animals (Abd El-Hack and Alagawany, 2015). The effect of supplemental rosemary on blood metabolites of laying hens are shown in Table 4. Serum constituents were not significantly $(P>0.05)$ influenced by rosemary supplementation, except urea, total cholesterol, IgM and IgA. Dietary supplementation of rosemary exhibited a positive impact on IgM and total cholesterol, which is in accordance with Hashemipour et al. (2013). Compared with the control group, supplementation of diets with rosemary linearly and quadratically $(P<0.001$ and 0.062 , respectively) elevated the IgM concentration and depressed (linearly and quadratically; $P<0.001)$ IgA and total cholesterol levels in the serum of hens.

In the present study, the diet enriched in rosemary (3, 6 and $9 \mathrm{~g} \cdot \mathrm{kg}^{-1}$ diet) numerically reduced serum triglycerides and total cholesterol, as well as LDL-cholesterol concentrations, but HDL-cholesterol concentrations were elevated with the same addition. In partial accordance with the present findings, Bölükbaşi et al. (2008) reported that rosemary supplementation to laying hen diets significantly depressed serum triglyceride and total cholesterol levels. In the same context, Rahimi et al. (2011) pointed out that blood triglyceride, total and LDL-cholesterol concentrations were significantly reduced by addition of PFA to chicken diets, but HDL-cholesterol concentrations increased. Radwan et al. (2008) observed that layers fed diets sup-

Table 4. Effects of rosemary powder on blood components in laying hens at 52 week of age $(n=6)$

\begin{tabular}{|c|c|c|c|c|c|c|c|}
\hline \multirow{2}{*}{$\begin{array}{l}\text { Blood } \\
\text { components }\end{array}$} & \multicolumn{4}{|c|}{ Rosemary powder, $\mathrm{g} \cdot \mathrm{kg}^{-1}$ diet } & \multirow{2}{*}{ SEM ${ }^{1}$} & \multicolumn{2}{|l|}{$P^{2}$} \\
\hline & 0 & 3 & 6 & 9 & & linear $c$ & quadratic \\
\hline \multicolumn{8}{|l|}{$\mathrm{g} \cdot \mathrm{dl}^{-1}$} \\
\hline total protein & 4.47 & 4.83 & 5.20 & 5.09 & 0.13 & 0.074 & $4 \quad 0.370$ \\
\hline albumin & 2.45 & 2.35 & 2.56 & 2.55 & 0.04 & 0.222 & 20.615 \\
\hline urea & 2.47 & 1.46 & 2.17 & 2.87 & 0.18 & 0.010 & 0.060 \\
\hline \multicolumn{8}{|c|}{ Lipid parameters, $\mathrm{mg} \cdot \mathrm{dl}^{-1}$} \\
\hline $\begin{array}{ll}\text { triglycerides } & 1\end{array}$ & 183 & 141 & 124 & 167 & 15.98 & 0.417 & $\begin{array}{ll}7 & 0.064\end{array}$ \\
\hline total cholesterol 1 & 171 & 129 & 127 & 119 & 5.92 & $<0.001$ & $1<0.001$ \\
\hline HDL-cholesterol & 93.28 & 134.00 & 95.00 & 93.01 & 9.05 & 0.616 & $6 \quad 0.247$ \\
\hline LDL-cholesterol & 56.61 & 43.00 & 42.46 & 37.30 & 3.73 & 0.105 & $5 \quad 0.571$ \\
\hline \multicolumn{8}{|c|}{ Immunoglobulin, $\mathrm{mg} \cdot \mathrm{dl}^{-1}$} \\
\hline $\lg G$ & 1.27 & 2.09 & 2.00 & 1.78 & 0.14 & 0.854 & 40.130 \\
\hline $\lg M$ & 12.54 & 14.75 & 17.95 & 517.74 & 0.71 & $<0.001$ & 0.062 \\
\hline $\lg A$ & 85.55 & 53.00 & 57.34 & 465.02 & 8.68 & $<0.001$ & $1<0.001$ \\
\hline
\end{tabular}

${ }^{1}$ SEM - standard error of means; ${ }^{2}$ linear and quadratic effect of rosemary supplementation 
plemented with rosemary leaves at $0.5 \%$ or $1 \%$ had lower $(P<0.05)$ total lipids level, while the concentrations of total cholesterol, HDL- and LDL-cholesterol in serum were not affected in the same way with the various rosemary supplementations compared with the control group. In contrast, Abd El-Latif et al. (2013) found that addition of rosemary to chicken diets led to increased serum concentrations of TG, total cholesterol and LDL-cholesterol, while concentrations of total protein, albumin and uric acid did not show significant changes. Also, Osman et al. (2010) noted that rosemary supplementation at levels of 0.5 and $1 \mathrm{~g} \cdot \mathrm{kg}^{-1}$ diet did not significantly affect the serum concentration of protein, albumin, creatinine or cholesterol.

Medicinal plants or their products often influence blood lipid parameters in opposing ways (Alagawany et al., 2015a,b). Hyperlipidaemic effects were reported with certain herbal plants (Bölükbaşi et al., 2006; Alagawany et al., 2015a), whereas hyperlipidaemia was seen with others (Farag et al., 2014). The discrepancies among these studies might be due to the differences in the PFA used, product type (powder, essential oil, phenolic compounds, etc.), doses and style of administration, as well as experimental conditions.

There are a large number of herbal plants having immunomodulatory properties that have been used to provide alternative potential to traditional chemotherapy for several of diseases, especially diseases related to immunodeficiency (Kumar et al., 2011; Farag et al., 2014). In the poultry industry, it is important to elevate the immune system to reduce or prevent infectious diseases. A variety of factors such as failure in vaccination and abuse of antibiotics can induce immunodeficiency and infection by immunesuppressive diseases. Using immune enhancers is a key solution to the problem of improving immunity and reducing susceptibility to infectious disease in poultry farms. Those PFA that are rich in flavonoids extend the biological activity of ascorbic acid, act as antioxidants and may enhance immune function (Acamovic and Brooker, 2005). These findings can partially explain the nutritional and biological effects of treatments on immune parameters presented in Table 4.

Addition of rosemary to layer diets may improve their serum IgM concentration versus the control diet. In previous studies it was reported that medicinal plants and their components could activate such immune functions as lymphocyte proliferation, phagocytosis, and red blood cell, haemoglobin and white blood cell counts (Hashemipour et al., 2013; Alagawany et al., 2015b).

\section{Antioxidant indices}

The antioxidant properties of aromatic herbs deserve special attention because undesirable oxidation produces unacceptable changes in flavour, colour, odour, and other quality factors of the eggshell. The effect of dietary rosemary on antioxidant parameters, including serum activity of superoxide dismutase (SOD) and concentrations of reduced glutathione (GSH) and malondialdehyde (MDA) of hens, is illustrated in Table 5. Serum SOD activity was linearly and quadratically $(P<0.01)$ increased in the rosemary groups, and reached a maximum $\left(290 \mathrm{U} \cdot \mathrm{ml}^{-1}\right)$ at $6 \mathrm{~g} \cdot \mathrm{kg}^{-1}$ diet. The GSH and MDA concentrations were not linearly and quadratically influenced in comparison with the control group. Hashemipour et al. (2013) noted that the intake of herbs or their contents resulted in an increase in serum antioxidant enzyme activities such as SOD and glutathione peroxidase (GSH-Px) and a decrease in the MDA concentration. Elevated levels of antioxidant enzymes may improve the steady state of the antioxidant system of poultry. SOD is metalloprotein enzyme whose main activity is in the antioxidant defense system. Lopez-Bote et al. (1998) demonstrated that the MDA concentrations in meat from chickens fed diets supplemented with rosemary and sage extracts ranged from 0.30 to $0.35 \mathrm{mg} \mathrm{MDA} \cdot \mathrm{kg}^{-1}$ meat, and were significantly lower than those from chickens fed on the control diet not enriched with antioxidants.

It seems that rosemary supplementation to layer diets was effective in enhancing the antioxidant ability of birds. Rosemary is a rich source of beneficial phenolic compounds, carnosol, carnosic and rosmarinic acids, and related effective compounds having strong antioxidant, anti-cancer and antiinflammatory activities (Chun et al., 2014; RocíoTeruel et al., 2015). Herbal additives may act by more than one mechanism, affecting feed intake and conversion, stimulating the secretion of digestive enzymes and gastrointestinal motility, as well as immune and endocrine functions in addition to their antioxidant, antimicrobial, antiviral, anti-

Table 5. Effects of rosemary powder on superoxide dismutase (SOD) activity reduced glutathione (GSH) and malondialdehyde (MDA) concentrations in serum of laying hens at 52 week of age $(n=6)$

\begin{tabular}{|c|c|c|c|c|c|c|c|}
\hline \multirow{2}{*}{$\begin{array}{l}\text { Oxidative } \\
\text { status }\end{array}$} & \multicolumn{4}{|c|}{ Rosemary powder, $\mathrm{g} \cdot \mathrm{kg}^{-1}$ diet } & \multirow{2}{*}{ SEM ${ }^{1}$} & \multicolumn{2}{|l|}{$P^{2}$} \\
\hline & 0 & 3 & 6 & 9 & & linear & quadratic \\
\hline $\mathrm{SOD}, \mathrm{U} \cdot \mathrm{ml}^{-1}$ & 207 & 269 & 290 & 257 & 10.20 & 0.007 & 0.002 \\
\hline $\mathrm{GSH}, \mathrm{ng} \cdot \mathrm{ml}^{-1}$ & 9.02 & 9.24 & 15.46 & 9.19 & 1.13 & 0.438 & 0.117 \\
\hline MDA, $\mu \mathrm{mol}$ & 4.47 & 4.51 & 4.41 & 3.89 & 0.31 & 0.411 & 0.151 \\
\hline
\end{tabular}

${ }^{1} \mathrm{SEM}$ - standard error of means; ${ }^{2}$ linear and quadratic effect of rosemary supplementation 
inflammatory, anthelminthic and coccidiostatic activities(Hernández-Hernándezetal., 2009; Basmacioğlu Malayoğlu et al., 2010).

\section{Conclusions}

The results obtained in this experiment showed that rosemary supplementation to layer diets tended to improve egg number, egg mass, serum total cholesterol and immunoglobulin $\mathrm{M}$ concentrations, and superoxide dismutase activity, while reducing immunoglobulin A serum content without a positive or negative effects on final body weight, feed consumption, feed conversion ratio, egg weight, shell percent, yolk index and some blood constituents including total protein, albumin, high-density and low-density lipoprotein cholesterol, immunoglobulin $\mathrm{G}$ and reduced glutathione concentrations as well as lipid peroxidation. On the other hand, shell thickness increased with the dietary rosemary level, obtaining the highest values of shell thickness at $3 \mathrm{~g} \cdot \mathrm{kg}^{-1}$ diet, while the Haugh unit score decreased with increasing rosemary supplementation up to $6 \mathrm{~g} \cdot \mathrm{kg}^{-1}$ diet. In summary, rosemary may be used in laying hens, but further studies are required before arriving at definite conclusions.

\section{References}

Abd El-Hack M.E., Alagawany M., 2015. Performance, egg quality, blood profile, immune function, and antioxidant enzyme activities in laying hens fed diets with thyme powder. J. Anim. Feed Sci. 24, 127-133

Abd El-Latif A.S., Nahed S.S., Allam T.S., Ghazy E.W., 2013. The effects of rosemary (Rosemarinus afficinalis) and garlic (Allium sativum) essential oils on performance, hematological, biochemical and immunological parameters of broiler chickens. Brit. J. Poultry Sci. 2, 16-24

Acamovic T., Brooker J.D., 2005. Biochemistry of plant secondary metabolites and their effects in animals. Proc. Nutr. Soc. 64 , 403-412

Akiba Y., Jensen L.S., Bart C.R., Kraeling R.R., 1982. Plasma estradiol, thyroid hormones, and liver lipid content in laying hens fed different isocaloric diets. J. Nutr. 112, 299-308

Alagawany M., Farag M.R., Dhama K., 2015b. Nutritional and biological effects of turmeric (Curcuma longa) supplementation on performance, serum biochemical parameters and oxidative status of broiler chicks exposed to endosulfan in the diets. Asian J. Anim. Vet. Adv. 10, 86-96

Alagawany M., Farag M.R., Dhama K., Abd El-Hack M.E., Tiwari R., Alam G.M., 2015a. Mechanisms and beneficial applications of resveratrol as feed additive in animal and poultry nutrition: A review. Int. J. Pharmacol. 11, 213-221

Alçiçek A., Bozkurt M., Çabuk M., 2003. The effect of an essential oil combination derived from selected herbs growing wild in Turkey on broiler performance. S. Afr. J. Anim. Sci. 33, 89-94
Angioni A., Barra A., Cereti E., Barile D., Coïsson J.D., Arlorio M., Dessi S., Coroneo V., Cabras P., 2004. Chemical composition, plant genetic differences, antimicrobial and antifungal activity investigation of the essential oil of Rosmarinus officinalis $L$. J. Agr. Food Chem. 52, 3530-3535

Basmacioğlu Malayoğlu H., Baysal Ş., Misirlioğlu Z., Polat M., Yilmaz H., Turan N., 2010. Effects of oregano essential oil with or without feed enzymes on growth performance, digestive enzyme, nutrient digestibility, lipid metabolism and immune response of broilers fed on wheat-soybean meal diets. Brit. Poultry Sci. 51, 67-80

Basmacioğlu Malayoğlu H., Tokuşoğlu Ö., Ergül M., 2004. The effect of oregano and rosemary essential oils or alphatocopheryl acetate on performance and lipid oxidation of meat enriched with n-3 PUFA's in broilers. S. Afr. J. Anim. Sci. 34, 197-210

Beutler E., Duron O., Kelly B.M., 1963. Improved method for the determination of blood glutathione. J. Lab. Clin. Med. 61, 882-888

Bölükbaşi Ş.C., Erhan M.K., Kaynar Ö., 2008. The effect of feeding thyme, sage and rosemary oil on laying hen performance, cholesterol and some proteins ratio of egg yolk and Escherichia coli count in feces. Arch. Geflügelk. 72, 231-237

Bölükbaşi Ş.C., Erhan M.K., Özkan A., 2006. Effect of dietary thyme oil and vitamin $E$ on growth, lipid oxidation, meat fatty acid composition and serum lipoproteins of broilers. S. Afr. J. Anim. Sci. 36, 189-196

Botsoglou N., Florou-Paneri P., Botsoglou E., Dotas V., Giannenas I., Koidis A., Mitrakos P., 2005. The effect of feeding rosemary, oregano, saffron and a-tocopheryl acetate on hen performance and oxidative stability of eggs. S. Afr. J. Anim. Sci. 35, 143-151

Bozin B., Mimica-Dukic N., Simin N., Anackov G., 2006. Characterization of the volatile composition of essential oils of some Lamiaceae spices and the antimicrobial and antioxidant activities of the entire oils. J. Agr. Food Chem. 54, 1822-1828

Cho J.H., Kim H.J., Kim I.H., 2014. Effects of phytogenic feed additive on growth performance, digestibility, blood metabolites, intestinal microbiota, meat color and relative organ weight after oral challenge with Clostridium perfringens in broilers. Livest. Sci. 160, 82-88

Chun K.S., Kundu J., Chae I.G., Kundu J.K., 2014. Carnosol: a phenolic diterpene with cancer chemopreventive potential. J. Cancer Prev. 19, 103-110

Farag M.R., Alagawany M.M., Dhama K., 2014. Antidotal effect of turmeric (Curcuma longa) against endosulfan-induced cytogenotoxicity and immunotoxicity in broiler chicks. Int. J. Pharmacol. 10, 429-439

Florou-Paneri P., Dotas D., Mitsopoulos I., Dotas V., Botsoglou E., Nikolakakis I., Botsoglou N., 2006. Effect of feeding rosemary and a-tocopheryl acetate on hen performance and egg quality. J. Poultry Sci. 43, 143-149

Hashemipour H., Kermanshahi H., Golian A., Veldkamp T., 2013. Effect of thymol and carvacrol feed supplementation on performance, antioxidant enzyme activities, fatty acid composition, digestive enzyme activities, and immune response in broiler chickens. Poultry Sci. 92, 2059-2069

Hernández-Hernández E., Ponce-Alquicira E., Jaramillo-Flores M.E., Guerrero Legarreta I., 2009. Antioxidant effect rosemary (Rosmarinus officinalis L.) and oregano (Origanum vulgare L.) extracts on TBARS and colour of model raw pork batters. Meat Sci. 81, 410-417

Hong J.C., Steiner T., Aufy A., Lien T.F., 2012. Effects of supplemental essential oil on growth performance, lipid metabolites and immunity, intestinal characteristics, microbiota and carcass traits in broilers. Livest. Sci. 144, 253-262 
Jang I.S., Ko Y.H., Yang H.Y. et al., 2004. Influence of essential oil components on growth performance and the functional activity of the pancreas and small intestine in broiler chickens. Asian-Austr. J. Anim Sci. 17, 394-400

Jensen C., Engberg R., Jakobsen K., Skibsted L.H., Bertelsen G., 1997. Influence of the oxidative quality of dietary oil on broiler meat storage stability. Meat Sci. 47, 211-222

Kumar S.V., Kumar S.P., Rupesh D., Nitin K., 2011. Immunomodulatory effects of some traditional medicinal plants. J. Chem. Pharm. Res. 3, 675-684

Lee K.W., Everts H., Kappert H.J., Frehner M., Losa R., Beynen A.C., 2003. Effects of dietary essential oil components on growth performance, digestive enzymes and lipid metabolism in female broiler chickens. Brit. Poultry Sci. 44, 450-457

Lopez-Bote C.J., Gray J.I., Gomaa E.A., Flegal C.J., 1998. Effect of dietary administration of oil extracts from rosemary and sage on lipid oxidation in broiler meat. Brit. Poultry Sci. 39, 235-240

Moreno S., Scheyer T., Romano C.S., Vojnov A.A., 2006. Antioxidant and antimicrobial activities of rosemary extracts linked to their polyphenol composition. Free Radical Res. 40, 223-231

NRC, 1994. Nutrient Requirements of Poultry. gth $^{\text {th }}$ revised Edition. National Academy Press. Washington, DC

Osman M., Yakout H.M., Motawe H.F., Ezz El-Arab W.F., 2010. Productive, physiological, immunological and economical effects of supplementing natural feed additives to broiler diets. Egypt. Poult. Sci. 30, 25-53
Papageorgiou G., Botsoglou N., Govaris A., Giannenas I., lliadis S., Botsoglou E., 2003. Effect of dietary oregano oil and a-tocopheryl acetate supplementation on iron-induced lipid oxidation of turkey breast, thigh, liver and heart tissues. J. Anim. Physiol. Anim. Nutr. 87, 324-335

Radwan N.L., Hassan R.A., Qota E.M., Fayek H.M., 2008. Effect of natural antioxidant on oxidative stability of eggs and productive and reproductive performance of laying hens. Int. J. Poultry Sci. 7, 134-150

Rahimi S., Teymouri Zadeh Z., Karimi Torshizi M.A., Omidbaigi R., Rokni H., 2011. Effect of the three herbal extracts on growth performance, immune system, blood factors and intestinal selected bacterial population in broiler chickens. J. Agr. Sci. Tech. 13, 527-539

Rice-Evans C.A., Miller N.J., Bolwell P.G., Bramley P.M., Pridham J.B., 1995. The relative antioxidant activities of plant-derived polyphenolic flavonoids. Free Radical Res. 22, 375-383

Rocío-Teruel R.M., Garrido M.D., Espinosa M.C., Linares M.B., 2015. Effect of different format-solvent rosemary extracts (Rosmarinus officinalis) on frozen chicken nuggets quality. Food Chem. 172, 40-46

SPSS, 2008. Statistical Package for the Social Sciences, Ver. 17.0. SPSS Inc. Chicago, IL (USA)

Winterbourn C.C., Hawkins R.E., Brian M., Carrell R., 1975. The estimation of red cell superoxide dismutase activity. J. Lab. Clin. Med. 85, 337-341 